\title{
Video Art: Psychological Status of Orphans from the Unrest in the Three Southern Thai Province
}

\section{I-na Phuyuthanon}

Department Visual art, Faculty of Fine arts Srinakharinwirot University Sukhumvit 23, Wattana, Bangkok 10110, Thailand

email: nananashow@gmail.com

\begin{abstract}
The greatest loss caused by the insurgency in Narathiwat province which is in the south of Thailand is the lives of the orphans whose parents or beloved ones have been deprived among conflicts and violence. Even though the affected people have received different aids, such cases are not as important as the situation faced by the orphans. After the losses, no one truly pays attention to the extent to which the southern crisis affects these unfortunate children. Even in time of peace, the children who will become adults in future have to face and suffers from severe social biases at home and elsewhere. They also have to face violence and the lack of safety in their lives. This is a result of the fire of vengeance between local people and the government's suppression which is a game of those villains in power. The orphans will have to sustain their lives alone despite some aids from the government and private sectors.

In order to create social awareness of the orphans' daily lives in Narathiwat province, which affects their psychological status, education, and security of individual, social, and country's levels, the awareness is raised through video art creation. Video art is a form of art which can reflects the way of lives of those who suffer from losses by presenting the stories of those who have lost, especially in terms of mental status after the loss. Video arts also present views and cultures of the locals with motion pictures, picture placement, and actions and contemporary artistic framework to convey the important message to the society so that people will understand the reality. Video arts are produced based on the researcher's viewpoints and attitudes gained from the five senses - vision, hearing, smell, taste and touch. Video art is also a type of media that fully responds to human's imaginations.
\end{abstract}

Keywords: Video Art, Psychology of Art.

\section{INTRODUCTION}

This research has been conducted for one year, since $27^{\text {th }}$ January 2015 to $26^{\text {th }}$ January 2016. In fact, this is a creative research as in VDO Art format that has been conducted information, sources, overall history and, most importantly, the loss of parents which caused by the political unrest in the three southern provinces. As a matter of fact, the issue has affected daily lives of orphans who struggle to live each day. This research will focus mainly on the minds of the living victims.

Since 2004, Narathiwat province is the most affected area in terms of loss and political unrest of the three provinces. It has been noted as the red zone, which unpredictable incidents always occur. The crisis in Narathiwat province causes changes and damage in many areas such as economy, society and way of living. Therefore, it is the province 
that has been under the strict control of the government ever since. Although many of the involved units are continuously trying their best to solve this problem - as in using internal and external authorities or even investing a great amount of money, the problem still incessantly goes on. Even worse, the violence has been increasing each day. We have lost lives, properties, economy, and security. It is a national issue that has occurs for too long and we do not know the real cause beneath this brutality or how we should solve it. Lives of innocent people, local staff including groups of people who use force to deal with this problem are affected every day.

Consequently, we are losing a sense of security. People are living with fright. The attack is reported daily. Victims are local people and we never know who will be the next one. The civil disorder has been developing its severity continually. To handle this, the government has responded by putting more soldiers and polices into the area to take care of the issue at maximum capacity. Authorities have put roadblocks in rural areas of the province, villages, sub-district and in the city area, but it doesn't work. Polices and soldiers have been attacked and killed every day. According to this matter, I have found that the attack on local staff will create fear of being close toofficials. People are afraid that they might get killed as well for doing so. Indeed, it is a conflict of belief that where there is police and soldier, it is not safe. Once I have actually gone there, I have sensed the gloom and depression all over the place. In addition, I've found that instigators will have their targets locked prior to the execution. The victims will be spied for some time before the actual attack begins. To be precise, some of the targets are not always officials. The random killings of local people, Thai Buddhist and Thai Muslim have installed nervousness, confusion and disorganization. Sometimes, it also is the source of accusation, carried by word of mouth all over the three southern provinces insurgency. Additionally, the rumors are being expanded within Thai society via certain medium, which are responsive to exchange comments. The innocent people are being attacked and accused as a consequence in certain period of time. Ways of living and local economy are both deteriorated by the unrest.

\section{MATERIALS AND METHODS}

Prof. Srisompob Chitpiromsri has given the interview in the $9^{\text {th }}$ article in the $9^{\text {th }}$ year in "the repetitive insurgency as in search for freedom of Pattani still continues", the Deep South Watch (DSW), Center for Conflict Studies and Cultural Diversity (CSCD), and Prince of Songkla University, Pattani Campus that the South Thailand insurgency has already been 105 months. Since January 2004 to September 2012, the total incidents are equal 12,377 times. As a result, the death toll and the injured are 14,890 people (Death 5,377 people. Injured 9,513 people). In 2012, 9 months have passed; there is a common belief that the unrest is becoming a chronic issue. Certainly, there is an attempt to make it obvious in terms of the increasing brutality in which the frequency and the intensity are still on the same scale, while the content of the violence are on the rise.

The insurgency has changed since 2007 up to present. Since 2012 onwards, it is clear that the custom of the violence has become more complex and intensified. Numbers 
of incidents are too horrendous and frightening to see. Also, some of the incidents are being broadcasted on media frequently. For instance, on March incident that 603 people were killed within the same period of time. Another case was in August; there were totally 380 attacks. All in all, we could say that the two months have broken the record of monthly political unrest frequency in nine years and nine months, since January 2004 to September 2012. The statistic of monthly unrest was high since January 2004. The recent violence reflects that the three southern provinces insurgency is now severe. It might be a symbolic proof of a qualitative damage and an evidence of inescapable chronic issue of the three provinces.

Isranews Agency has released a statistic number regarding southern insurgency matter. For the past eight years, there are 13,085 people affected. The death toll was totally 5,469 people and injured 9,653 people. The report in $29^{\text {th }}$ July 2012 is as below:

Early 2012, the incessantly unrest in the southern on Thailand on $31^{\text {st }}$ March, there was a car bomb in Had Yai, Songkla and another two in Ramadan. However, at that time, the local staff still insisted that, based on statistical information, the overall of the situation was getting better and obviously much better than last year. According to the unrest report, the insurgency of the southern provinces has continually happened in the past eight years, affected the living of people and official work life. The characteristics of the attack are ambush, landmine and demolition of personal and official properties. In 2004-2012, the total insurgency in the three provinces and Songkla equals 13,085 times, resulted as 5,496 death and 9,653 injured in which most of them are local people (75.04\%). The violence incidents are increasing up to 2,078 times. The situation in 2005, the government announced the Declaration of a State Emergency in 2005. However, the insurgency was at its peak in 2007, there were equally 2,475 incidents. The unrest was then starting to decrease in 2012 and there is a tendency to continuously go lower. Government has used the peaceful means, focusing on creating a local leader discussion forum in order to tackle with the problem with local insights.

This method opens up new idea for everybody to think of solution for the insurgency. Then the remedial measures of victims were brought to help those in the three southern provinces to change violence to peace. Nevertheless, even though the result of policy changing was not concrete to evaluate, but the average of the insurgency decreases from 2.97 in 2011 to 2.42 in 2012. Comparing statistic within six months, especially the ambush and landmine, incendiary incident between January to July 2011 and January to July 2012, reported by Southern Border Provinces Police Operation Center; the overall situation diminished from 406 times to 172 times. The bomb explosion has reduced from 147 in 2011 to 92 in 2012 or $37.41 \%$.

According to the Deep South Coordination Center (DSCC) and Prince of Songkla University, Pattani Campus have found that the statistic of the unrest in Pattani, Narathiwat and Yala in January to June 2011 comparing with the same period in 2012 , there is a tendency to decrease of insurgency in every province. The overall situation reduced from 511 incidents to 306 or $40.11 \%$. The casualty in the three border provinces between January to June 2011 compared with the same period in 2012, 
reduced from 234 incidents to 145 or $38.05 \%$. The total number of death toll between January to July 2011 comparing with the same period in 2012 has reduced around 216 people. Moreover, divided by province, Yala has death toll and injured figured decreased 78 people. For Pattani, the death rates and injured are more or less the same.

Regarding Narathiwat, the death toll and injured rate reduced 138 people. The risky targets are teachers and educational staff. Between January to June 2011, death rate: 5 and injured 4 people. However, in 2012 there was no mentioned target being attacked at all. In terms of crimes, in the areas of Provincial Police Region 8 responsibility (middle southern provinces) Region 9 (lower southern provinces) in the three border provinces and Sotocho(Southern Border Provinces Police Operation Center) have found that region 8 has the highest rat of crime. The average per day is 1.44 . On the other hand, Sotocho area has only 1.21 per day.

The budget to cease the fire of the three southern border provinces from www. isranews.org/south-news, written by PakornPeungnetre on the $4^{\text {th }}$ January 2012 reported that in the past eight years, the government has already invested 1.61 hundred billion baht. Moreover, especially in 2012 the government set up a budget of 1.6 ten billion baht for soldiers and Internal Securities Operations Command (ISOC) to empower their duties. More than $60 \%$, the situation did not get any better. In the eight years, there were over ten thousand times of insurgency, approximately 2.7 times per day and more than 2 thousand bombs occurred. Over five thousands people were killed because of the attack. More than 1.6 thousands of guns were stolen while the authorities can take the guns back only almost five hundred.

The political unrest in the three southern border provinces and four districs in Songkla would celebrate their $8^{\text {th }}$ anniversary in order to commemorate the incidents on $4^{\text {th }}$ January 2012 that officials were threatened and killed severely inside the $4^{\text {th }}$ Development Division, Kromluang Narathiwat Ratchanakarin Camp, Bann Pileng Tai, Maruebo-oke, JaoAirong District, Narathiwat Province. At that time, 413 guns were robbed. People are in continuous doubt if the government has been able to tackle the problem. During the crisis, Thailand has already been governed under the seven teams and six prime minister. However, the daily killing still exists while there was also a heavy investment on money to solve this.

According to the information, every changing government has put the insurgency to be a "national agenda" and; consequently, spent a great deal of money up to totally 161,278 million baht in nine years. The budget can be divided per year: in 2004, the government spent 13,450 million baht, 2005 - 13,674 million baht, 2006 - 14,207 million baht, 2007 - 17,526 million baht, 2008 - 22,988 million baht, 2009 - 27,547 million baht, 2010 - 16,507 million baht, 2011 - 19,102 million baht and 2015 budget is currently under consideration, the tentative of approved expenditure should be around 16,722 million baht. Nevertheless, we should take into account that the budget are "functional budget" of certain ministries and divisions which includes the spendings such as living expense for the Office of the National Security Council, under the supervision 
of ISOC. The budget excludes other funding such as monthly salary, extra costs of officials, budget for those who in need of recovery around three billion million baht.

On 21th April 2012, Isranews Agency has revealed about the disabled students in the three southern border provinces that the amount ofdisabled students are over five thousand, while other students are victims also affected. The latter group is around 350 people. The budget to help these students equals 155 million baht in order to create learning centers for disabled students to elevate their well-beings. The objective is to let them grow or live effectively and independently. The payment was beling split up three rounds: 7.5 million baht by Southern Border Provinces Administrative Centre (SBPAC), 3 million baht by Pattani and 4 million baht by government bond.

The SBPAC has used 155 million baht to set up a healthcare for disabled victims from the insurgency of the southern border provinces. After investigation, there are more than 5,000 disable children and over a hundred disabled people are taken cared of here. The meeting of strategic board of development, SBPAC 2/2015 has proposed that the total disable students in the three southern border provinces are up to 5,406 people, only 3\% of them has received a proper education. Therefore, parents have requested to install more schools for disabled children in the local areas so that they do not have to send their kids off to the center of those provinces. The total disabled population of students is 5,406 people: 1,230 people from Yala province, 3,446 Pattani and 1,730 from Narathiwat. For the victims of the insurgency that has become handicapped are as detailed: 350 from Yala, 157 Pattani, 123 Narathiwat and 7 people from Songkla. In terms of development and lift up education of disabled students and heal those affected from the attack, Office of The Basic Education Commission and Bureau of Special Education have proposed to set up education centers and health care to take care of the disabled victims in Budi, Yala because of the free space of 30 Rai. In this case, the budget for all cost are around 155.639 million baht. This is the budget between $2013-2015$.

The statistic of orphans and poor children from the three southern border provinces, written by Isara Institute (Isranews Agency), pointed out that the violence of the attack has caused children to become orphans approximately around 4,455 people. The total amount of orphans, which caused by the insurgency in four provinces from 2004-2011 are 4,455 people. Divided by provinces would be: 1,691 from Pattani, 1,027 Yala, 1586 Narathiwat and 150 from Songkla.

Since the insurgency in the three southern provinces is in a constant severity, numbers of people were killed. People are living with fear. Everybody is afraid of the next attack, they are afraid of the when and the how. Some of the local people even relocate to live in new locations in order to escape the violence, but the fright has been planted within their minds. I am one of those people who are afraid of losing somebody I love. I am in a constant fear of the next insurgency to come, wondering when it is going to happen and so on. Even though I have not heard anything from the news, just the thought of my hometown, my parents who live there, I cannot escape from the fear and anxiety. Since I cannot predict anything in the future, I could never be peaceful from what to come. 
Indeed, it is because the problem is deeply routed. I know for fact that the violence of the attack that is the source of orphans. Even though those who are affected from the incidents should be given money and support from the government, yet nobody really pays attention to this issue. No one cares how much it affects the lives of children. Although even when there is nothing happen, these children are already living among a war of social prejudice. Nonetheless, being in the middle of insurgency begets a lack of insecurity. It is the result of local people who fight with the government that tries to control the situation with force. I believe this is what the criminals have planned it to be. The lives of victims, orphans who have to take care of themselves are getting harder each day in the three southern provinces.

However, the orphans do not really express themselves and united with other people. They basically just repress their thoughts and feelings. Yet they are not angry of what had happened. As a matter of fact, they believed that it is their predestinations. Therefore, they still continue to live but mostly in gloom.

The purpose of the thesis is to expose the truth of how the orphans live in the three southern provinces, which affects their minds, education including inner securities of each individual and society. All of this is combined in creative VDO art format. The VDO art can broadcasts real lives of local people and the lives of those who have lost. Attitudes and cultures are portrayed in motions picture within the various layouts. It is a new way of representing art in the new era.

Other methods of creating this work of art are also included. The purpose of exhibiting is to express and show the fact as it is to the society. It is being crafted in my perspectives and my own five senses: see, hear, smell, taste and touch. I believe that the VDO art are very responsive to our imaginations to know the in-depth story of the orphans about the way that they live in Pattani, Yala and Narathiwat. This set is call "every day I fear" which regards the research that has been conducted to study the consequences of insurgency in the three southern border provinces of Thailand. It is a qualitative study.

In fact, I have been conducted an information and data for three years to make this happens via VDO Art. This research will further my experience of actually being in the areas, interviewing the victims and express all that I have to others. The reasons that I have chose this format is because it conveys our feelings. It is the one thing that can speak for the things that cannot in terms of what really happened over there. Currently, the insurgency still exists. Additionally, I'd like to make this fact known and more approachable than the previous work that comes from more experiences in real lives.

\section{Methods of conducting}

The format for this whole research is in VDO art. It collects all the information to create a virtual atmosphere of orphans' feelings and minds from the political unrest in the three southern border provinces, which are Yala, Pattani and Narathiwat. This is to create an awareness of the true story and consider the future of children in those provinces or even the future of the country. Children who live and grow among a war 
will be the future of the nation as well. As I have been into the red ares, I have divided the three provinces into two sections.

First is the search from sources such as books, journals and newspaper, television and internet, etc.

The second section is the on-site investigation.

- The first province to inspect is my hometown, Yala province, for my own safety and convenience.

- The second province is Pattani. I've keen on this province since I used to study in the local school, Leam Thong Upathumschool, and lived with my grandmother there at Puyud, Pattani.

- The third province is Narathiwat. This is the province that has lost most of the population because of the unrest.

The on-site investigation has taken place on $1^{\text {st }}$ April 2015 to $31^{\text {st }}$ July 2015. The details will be as followed:

\section{Yala Province}

I've chose to study this province first since, as mentioned above, it is my birth place. The actual date to start was April 2015.

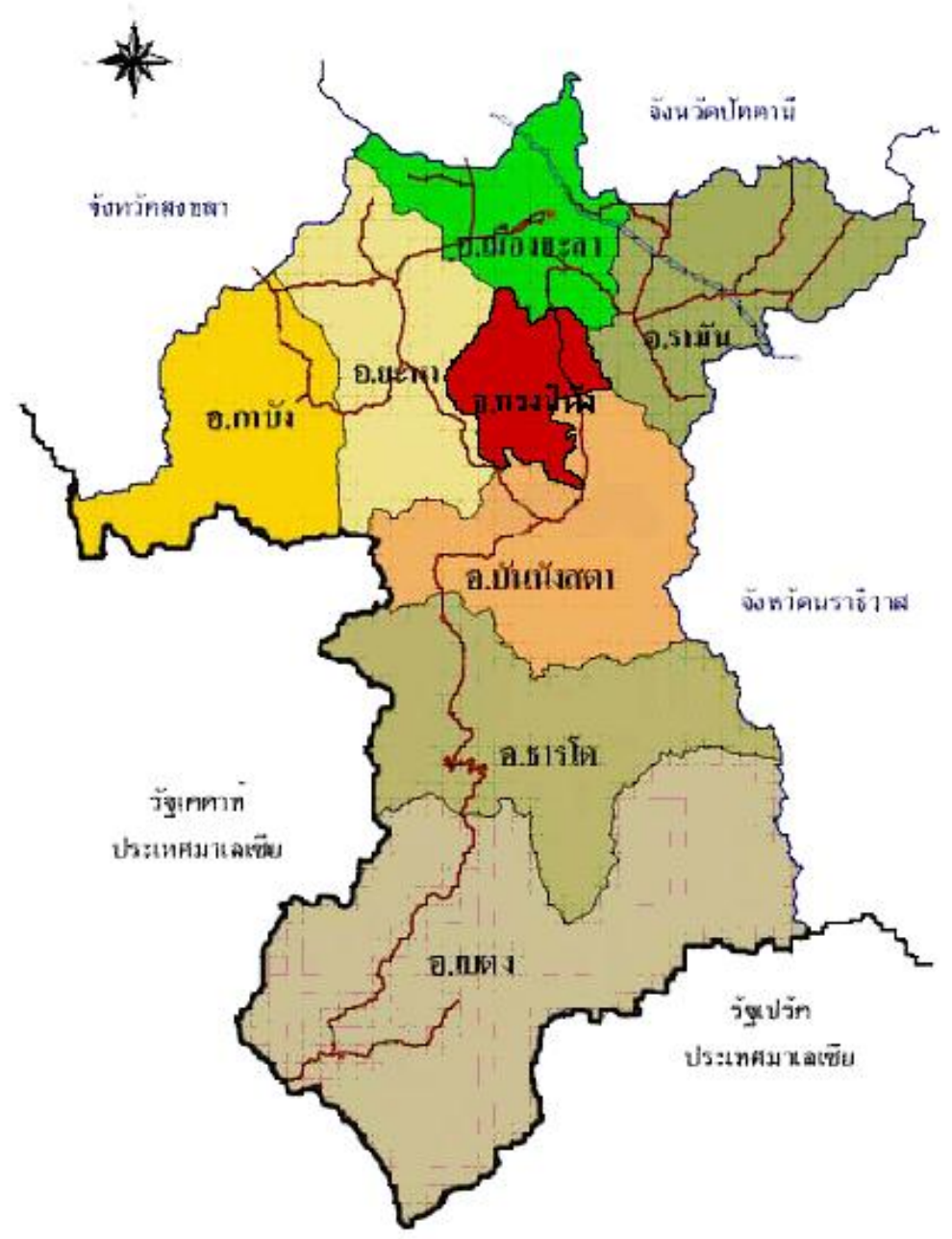

Source of picture: http://www.yala.go.th/webyala/SiteMap/history1.html 
I've investigated this areas by researching the history and profile of each household via observation, interview based on Ta-Se sub-district and Yu-po sub-district, Meung district.

As interviewed directly with the orphans, I noticed that they are trying hard to make eye contact and even harder an attempt to smile. For instance, I have listed a short answer when they answered the question.

1. Yesterday I came home.

2. I live in Ta-Kod.

3. Since $7^{\text {th }}$ grade.

4. Dad died in 2014.

5. Around the $7^{\text {th }}$ grade.

6. He was shot at our home.

7. There was an attack. He died around 4.30 am on Friday, after he came back from the mosque.

8. Well, he was shot.

9. Then I have a brother who was only 40 days old.

10. I was very sad because he is the one who took care of us.

11. We're close. I always go with him anywhere.

12. He usually took me to have something delicious before go to school. We also love going to drink tea together at a nearby tea shop.

13. Well, It's different when I still had him.

To decode the interview, I've sense their mentality and I could feel it from our first encounter. Also, I have used her answers to create as a part of VDO art via story board to express the real story to public.

\section{Pattani Province}

I've chosen as the second location of investigation because it is one of the places where I used to live. I also studied there from $1^{\text {st }}$ grade $-6^{\text {th }}$ grade. In fact, Pattani has a long history to study as well. The location I chose were: Pa-Se-Ya-Wo sub-district, Saiburi district, Puyud sub-district, Meung district, Panare district, Nongjik district, Ya Ring district, Ya Rung district, Kok Poe district, Ma Yor district, Tung Yang Deang district and Mae Lan district. 


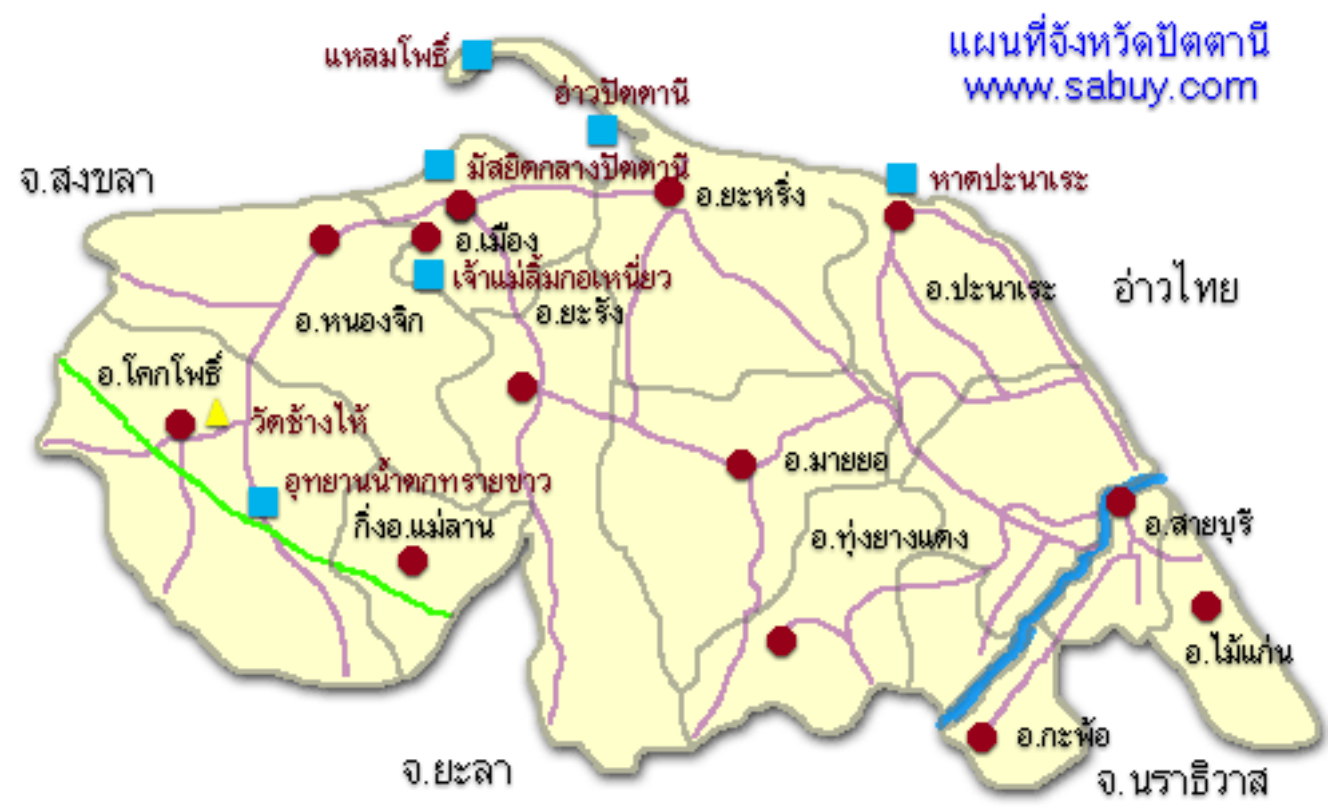

Source of picture:https:/ / nokngamphol.wordpress.com/แผนทีจังหวัดปัตตานี/อาณาเขตและการปกครอง/

Narathiwat Province

I used to lived there when I was young. Now, it has become a red zone which refers to the insurgency in that area. Narathiwat is the province that have lost most of its populations and political unrest incidents.

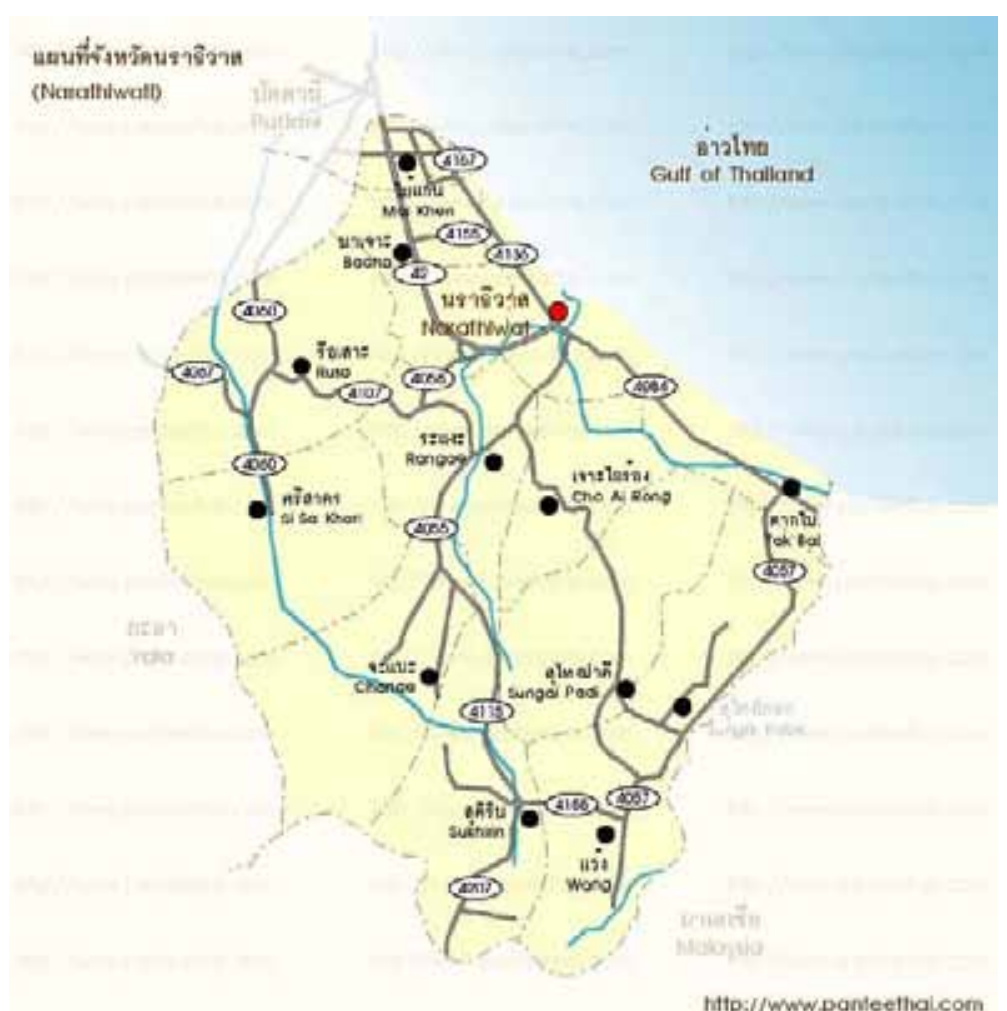

Source of picture: http://forums. panteethai.com/a/index.php?topic=1474.0 


\section{DISCUSSION}

\section{Design, Creativity and Development}

As examined with documents, on-site interview and take note from observation, I have gathered all the information and created a story board divided into two sections. My inner motivation comes from the fact that I have also lost my uncle, father's younger brother, and I used to observe the lives of his two sons his daughter.

\section{The first section of the board}

This includes the overall picture after the attack happened. Everything is green and full of trees, but it is perfectly dry in the eyes of those who've lost their beloved ones.

\section{The second section of the board}

This section shows the true presentation of orphans, their ways of living. This also includes the overall atmosphere of the house, schools, playgrounds and a meeting point where orphans are united.

\section{Problems and Obstacles}

The on-site investigation challenges me in terms of, most importantly and mainly, how to not hurt interviewees' feelings especially orphans. As a matter of fact, I have to know the true profiles and in-depth details of the orphans as well as to consult with the local psychiatrists. The creation of this VDO art set mostly brings out my personal perspectives in order to obviously express the problematic situation to society. I would like to make the fact known and feel the hardship those people have to endure in every day. In addition, in order to continue with lives, the only thing that holds orphans together religious belief. They believe it is the test from above that they must overcome.

\section{Exhibition}

a. $\quad 1^{\text {st }}$ event on 4-6 March A.D. 2013, Imaginasia, Nan province

Feedback: Professors from Taiwan suggested that they could only sense sadness but no fear expressed by people in the three southern provinces.

b. $\quad 2^{\text {nd }}$ event on 28 March - 18 May A.D. 2013

The researcher participated in the exhibition "Non-being by itself" (The state of non-existence by itself) by KaminLertchaiprasert, cultural experts and modern artists. The topic of the exhibition was "an impressive person". The researcher sent the video art to join the event, aiming to recount the story dominated by fears. Even if the researcher does not live in the three southern provinces, beloved people of the researcher live there, including the researcher's dearest father. He works in AMphurTakbai, Narathiwat. The researcher is afraid all the time, yet impressed by father's persistence to dedicate himself to working for the nation.

c. $\quad 3^{\text {rd }}$ event on 20-24 June A.D. 2013

Imagiasia International Workshop by Matsu County Government \& National Chengchi University.

Feedback: The researcher received complimentary remarks as the video captured viewers' attention with clear and sharp picture and sound. Most people felt sympathetic towards the unfortunate people who lost their beloved ones. However, their comment was that they could not understand fear which the researcher tried to express. 
d. $\quad 4^{\text {th }}$ event on 26-28 August A.D. 2013

A single exhibition at the art gallery, the Faculty of Fine Arts, Srinakharinwirot University.

"My Fear, My everyday"

(This time the pictures and the sounds of the video art were adjusted so that they were clearer. For example, the sound of people talking in tea shops, the sound of prayers to god, and the picture of people carrying a corpse to bury in Pattani).

Feedback: Most viewers said they saw another angle of the way of life in uncertainty, never knowing what would happen next. They had never known this point before.)

e. $\quad 5^{\text {th }}$ event on 4 September A.D. 2013

The researcher participated in the seminar project "IramaAsli: Hope in the Song of a White Pigeon"

This video art included the pictures of a widower (who had just lose her husband) living alone in Narathiwat.

Feedback: Most viewers do not live in the south and said that "They have never known what was really happening to the local people" for they knew only from $\mathrm{TV}$, newspapers, or internet. Most news only presents pictures and news of what happens, but not the lives of those who had to live on after the loss.

f. $\quad 6^{\text {th }}$ event on 17 March -19 April A.D. 2013

Exhibition title: Faith and Fairy Tales: New Media Art for Thailand at ADM

Gallery - NTU Singapore

Curator: LoredanaPazzini - Paracciani

Featured Artist: PiyatatHemmatat, NawapolThamrongrathanarit, KaensanRattanasomrerk, TaikiSakpisit, ChualayarnnonSiriphol, and I-naPhuyuthanon

\section{RESULTS}

The research on "Video Art: Psychological Status of Orphans from the Unrest in the Three Southern Thai Provinces" enables the researcher to discover the approach to create video art to convey Orphans from the Unrest in the Three Southern Thai Provinces of those who lost their beloved so as to reinforce awareness of those who also live on the same land. The researcher has written storyboard, shot, recorded, and edited photos and sounds, all of which can be examples or guidelines to create such kind of work in the inhabited area. Those who are involved or strive to sort out the insurgent crisis in the three southern provinces may have different understanding and perspective of Islam, or may not understand Thai Muslim people. The communication through video art can serve as a means to build up understanding of the unhappy lives in the three southern provinces. Such understanding is essential because the issue in the three southern provinces is sophisticated and dynamic. It is important to take a very close look at the problem affecting the people who live in the area as the problem has been around and does not seem to be better in a short course of time. The researcher, as the creator of the art, is inspired by the fear in own home town, and thus has conducted this research to convey the learning through this piece of artwork with the aspiration to be of benefits to those who would like to study this subject later on. 


\section{CONCLUSION}

\section{Work as a Product of Creative Research}

The creative research "Video Art : Psychological Status of Orphans from the Unrest in the Three Southern Thai Provinces" has followed creative research methodology. The researcher would like to present this piece of creative research with the following conclusion:

The insurgency in the three southern provinces keeps aggravating while nobody really knows the pain of those who have lost everything ranging from their beloved people parents, spouses, offspring, relatives, friends, and properties - and even their privacy. The effect will never fade away and the broken-hearted will never be healed. The people in the three southern provinces still fear and wonder why and when they will become victims endlessly. They are unsuspecting targets and will continue to be till the end. What exactly is the cause of the insurgency? This question has been raised time and again while answers have been given by various sectors for a long time. The one thing that keeps the local people alive is their religion, to which they hold on. Their religion is the key to their survival in the current social circumstances.

The never ending loss causes fear to the local residents because the incident could even happen in their homes. Humans and animals instinctively protect themselves all the time, thus sometimes becoming over precaution just to ensure they will survive. Excessive fear can have a detrimental effect unless it is laid down. Excessive fear is not a self-protective way, yet it happens uncontrollably.

Youtube link: http://youtu.be/U-5pqeQKpiI

\section{REFERENCES}

Arpornsuwan, Thanes. (2012), Background of Land Segregation Theories in the South of Thailand. Bangkok: Foundation of Social Science and Anthropology Textbooks Program.

Chaithongpan, Prasit. (2009), They Accuse (NujMuddin) an Insurgent. Bangkok: Saiyai Prachachon.

Chanchadfah, Suppara.(2006), Violence in the Mist: What is What in Three Southern Border Provinces. Bangkok: JatpimKobfa.

Chantavanich, Supang.(2008), Qualitative Research Methodology. Bangkok: Dansutth. wankaew, Surichai, Origin of Southern Fire. Bangkok: Thammada Press.

Chantavanich, Supang. (2012), Social Science Theories. Bangkok: Tawee Print. wankeaw, Surichai. (2007), Termination of Southern Fire. Bangkok: Thammada Press.

Jehsorhoh,Jehabdulloh. (2011), "Appearance of Local Malays in Pattani Art Exhibition." Bangkok: Queen Sirikit Art Gallery.

Kanpai, Kitti. (2008), Communication Psychology. Bangkok: Rien-Boon.

Konsanjorn, Dime.( 2007), Southern Fire-Devoted to Sacrificing Teachers. Bangkok: Wiriya Business.

Manakit, Peerapong. (2011), Epic of Three Southern Border Provinces. Bangkok: Roongreungsarn.

Nararatwong, Chumsak. (2009), Southern Fire Crisis. Bangkok: Huajai-Diewkan.

Nararatwong, Chumsak. (2009), Under the Memory. Bangkok: Huajai-Diewkan. 
Nunsathaporn, Piyasin.(2012), Composition of Origins and Roots of Humanity Inequality. Bangkok: Siam Pritas.

Panpong, Worapoj. (2007), Crime Scences. Bangkok: Open Books.

Patan, Muhammad-Aryub. (2013), Process of Pattani's Peace in Asian Context.Pattani: Parp-Pim.

Pengjan, Pramuan. (2012), Walk of Peace in Pattani. Bangkok: Charoendeemankong.

Prasongbandit, Sunee. (2010), Pierre Bourdieu's Habitas Concept and Anthropology Theories. Bangkok: Sirintorn Anthropology Center.

Samaputthi, Kulthida. (2009), Power of Life, Power of Mind: Fifty Voices from Southern Border Women. Bangkok: Dan-Sathu.

Sarntisart, Isra. (2010), Nabi-Muhammad, Mercy of Humanity. Bangkok: Mark M Printing.

Sarochamas, Panpimon.( 1995), Thesis onRoles of Muslim Newspapers in Thailand. Bangkok: Chulalongkorn University.

Siamwalla, Ammar. (2006), Conflict between Development and Social State of Three Southern Border Provinces. Bangkok: Dhurakij Pundit University.

Tangcharoen,Wirun. (2010),Vision of Fine and Applied Arts. Bangkok: Santisiri.

Tangsabwattana, Ek, PhucharoenOraorn. (2009), Problems of Three Southern Border Provinces: Policy Suggestions. Bangkok: WePrint.

Usman, Suf-Um.(2004), Islamic Way of Freedom. Bangkok: Islamic Academy. 